\title{
Estimation of Thionein Synthesis in Cultured Cells by Slab Gel Electrophoresis
}

\author{
Shinji KOIZUMI, Noriko OTAKI and Masami KIMURA \\ Department of Experimental Toxicology, National Institute of \\ Industrial Health, 21-1, Nagao 6-chome, Tama-ku, \\ Kawasaki, 213 Japan
}

(Received March 10, 1982)

\begin{abstract}
For detection of thioneins induced in cultured rabbit kidney cells after exposure to $\mathrm{Cd}^{++}$, the cytosol fraction of ${ }^{35} \mathrm{~S}$-cysteine-labeled cells was carboxymethylated and subjected to SDS-gel electrophoresis. By fluorography of the gel, labeled thioneins were specifically detected in the cytosol of $\mathrm{Cd}^{++}$-treated cells while not in untreted control cells. Relative amounts of the labeled thioneins can be estimated by this method, since densitometrical concentrations of the thionein bands on the fluorogram were proportional to the amounts of the proteins applied to the gel. Moreover, isometallothioneins could be separated by this procedure.
\end{abstract}

Keywords : Metallothionein-Cadmium-Cultured rabbit kidney cell-Carboxymethylation-Gel electrophoresis

\section{INTRODUCTION}

Metallothioneins (MTs) are low-molecular-weight cysteine-rich proteins that bind such metals as $\mathrm{Cd}^{++}, \mathrm{Zn}^{++}$and $\mathrm{Cu}^{++1}$. Synthesis of thioneins, the apoprotein moieties of MTs, is induced when animals or cultured cells are exposed to these metals. Because of this characteristic, it has been postulated that MTs have a protective role against toxic heavy metals, or are involved in the metabolism of essential metals ${ }^{1)}$. We previously reported that cellular MT levels after $\mathrm{Cd}^{++}$exposure are quite variable in livers of mice of different strains ${ }^{2}$ and in various cultured cell lines ${ }^{3}$. For further study of the significance of these variations, a convenient method for measuring newly synthesized thioneins is required. Slab gel electrophoresis of proteins labeled with a radioactive amino acid is suitable for this purpose, since multiple samples can be treated in a short time. In this report, we examine the usefulness of this method, using $\mathrm{Cd}^{++}$-exposed rabbit kidney cell cultures.

\section{Materials ANd Methods}

1 Cell culture and labeling of cellular proteins

RK-13 cells, of an established cell line derived from rabbit kidney, were cul- 
tured in Eagle's MEM supplemented with $10 \%$ calf serum at $37^{\circ} \mathrm{C}$ in a humidified $5 \% \mathrm{CO}_{2}$-incubator. For labeling of the cellular proteins, the cells were inoculated at $8 \times 10^{5}$ cells $/ 10 \mathrm{~m} l$ of medium/9-cm plastic dish (FALCON) and cultured for 3 days. They were then given antibiotics ( $100 \mathrm{mcg}$ of streptomycin and $100 \mathrm{U}$ of penicillin per $\mathrm{ml}), \mathrm{CdCl}_{2}\left(1 \mu \mathrm{g}\right.$ of $\left.\mathrm{Cd}^{++} / \mathrm{ml}\right)$ or distilled water, and ${ }^{35} \mathrm{~S}$-cysteine. The concentrations and specific activities of the ${ }^{35} \mathrm{~S}$-cysteine as well as the labeling periods are shown in the figure legends.

\section{Preparation of cell extracts}

${ }^{35}$ S-cysteine-labeled cells were harvested with $0.05 \%$ trypsin/0.02\% EDTA,

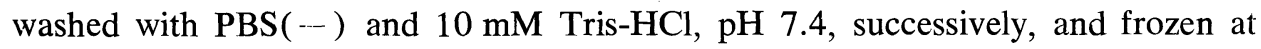
$-80^{\circ} \mathrm{C}$ until used. After being thawed, the cells were resuspended in $10 \mathrm{mM}$ Tris- $\mathrm{HCl}$, $\mathrm{pH} 7.4$, to $2 \times 10^{7}$ cells $/ \mathrm{ml}$ and allowed to stand at $0^{\circ} \mathrm{C}$ for $10 \mathrm{~min}$. The cells were then homogenized with 10 strokes of a Potter-Elvehjem homogenizer with a teflon pestle, and centrifuged at an average of $105,000 \times \mathrm{g}$ for $60 \mathrm{~min}$. The supernatant cytosol fractions were used for the experiments. The concentration of protein in the cytosols, determined by the method of Lowry et al. ${ }^{4}$, was about $2 \mathrm{mg} / \mathrm{ml}$.

\section{Purification of mouse and rabbit liver MTs}

MT-I and MT-II were purified from livers of mice or rabbits by ethanol precipitation, Sephadex G-75 gel filtration and DEAE-Sephadex A-25 ion exchange chromatography as previously described ${ }^{5)}$. Protein amounts of the purified MTs were determined by weighing the lyophilized samples.

\section{Carboxymethylation of proteins}

Protein solutions $(10 \mu l)$ were mixed with $5 \mu l$ of $0.2 \mathrm{M}$ Tris- $\mathrm{HCl}$ buffer $(\mathrm{pH}$ 8.8 ) containing $8 \%$ sodium dodecyl sulphate (SDS) and $50 \%$ glycerol and $2 \mu \mathrm{l}$ of $0.2 \mathrm{M}$ dithioerythritol (DTE), and then boiled for $5 \mathrm{~min}$. After the mixture was cooled, $3 \mu l$ of recrystallized iodoacetic acid (IA) solution (1 M solution adjusted to about $\mathrm{pH} 8$ with $\mathrm{NaOH}$ just before use) was added and the mixture was incubated at $50^{\circ} \mathrm{C}$ for $15 \mathrm{~min}$.

\section{SDS-polyacrylamide gel electrophoresis and fluorography}

SDS-15\% polyacrylamide slab gels (1 mm thick) and eiectrode buffer were prepared according to the method of Laemmli ${ }^{6}$. The carboxymethylated protein solutions (5-20 $\mu \mathrm{l} / 2.5$ - or $4.5-\mathrm{mm}$ slot) were mixed with $1 / 10$ volume of $0.1 \%$ bromophenol blue (BPB) and applied to the gels (10-cm running gels). Electrophoresis was performed at $45-50 \mathrm{~V}$ for $12-14 \mathrm{hr}$ until the BPB reached about $9 \mathrm{~cm}$ from the starting edge of the running gel. After fixation in 10\% trichloroacetic acid $/ 10 \%$ acetic acid/30\% methanol for $1 \mathrm{hr}$, the gels were soaked in three volumes of autoradiography enhancer solution (EN ${ }^{3} \mathrm{HANCE}$, New England 
Nuclear) for $1 \mathrm{hr}$ and then in water for another hour with two or three changes of water. All procedures from the fixation step on were done with gentle shaking. The gels were dried on filter paper with a Hoefer slab gel drier. Kodak X-Omat RP film was exposed to the dried gel sheets at $-70^{\circ} \mathrm{C}$ for appropriate times. The developed film was analyzed by a densitometer, Jookoo Densitron model PAN, at $540 \mathrm{~nm}$. When proteins were detected by staining, the gels were soaked in $0.025 \%$ Coomassie brilliant blue $/ 10 \%$ acetic acid $/ 50 \%$ methanol with gentle shaking for $1 \mathrm{hr}$, then destained in $7 \%$ acetic acid $/ 25 \%$ methanol for severa! hours.

\section{Chemicals}

The Eagle's MEM was from Nissui Seiyaku Co., Ltd., Tokyo, Japan. The calf serum, trypsin and antibiotics were from GIBCO, USA. Sephadex G-75 and DEAE-Sephadex A-25 were from Pharmacia, Sweden. SDS and DTE were from Nakarai Chemicals, Ltd, Kyoto, Japan. The IA, acrylamide, ammonium persulphate and $\mathrm{N}, \mathrm{N}, \mathrm{N}^{\prime}, \mathrm{N}^{\prime}$-tetramethylethylenediamine were from Wako Pure Chemicals, Ltd., Osaka, Japan. The $\mathrm{N}, \mathrm{N}^{\prime}$-methylenebisacrylamide was from Seikagaku Kogyo Co., Ltd., Tokyo, Japan. The $\mathrm{CdCl}_{2}$ was from Merck, West Germany. The ${ }^{35}$ S-cysteine was from New England Nuclear, USA. The molecular weight markers (trypsin inhibitor, cytochrome C, aprotinin and insulin B chain, of molecular weights of $21.5,12.5,6.5$ and 3.4 kdaitons, respectively) were from Boehringer Mannheim, West Germany. All of the other chemicals were of high analytical grade.

\section{Results}

Thioneins are rich in sulfhydryl ( $\mathrm{SH})$ residues of cysteines and casily form intermolecular S-S linkages, which makes their analysis by sodium dodecyl sulphate (SDS)-gel electrophoresis difficult. To circumvent this problem, particularly in the analysis of cell-free translation products of thionein mRNAs, the SH residues of the proteins are blocked before electrophoresis ${ }^{7,8)}$. This treatment involves dissociation of metals from the proteins as weil as reduction of their SH residues by denaturants such as SDS or guanidine hydrochloride and reducing agents such as dithiothreitol or dithioerythritol (DTE), and carboxymethylation of the residues by incubation with iodoacetic acid (IA). We modified thioneins by this procedure, in which SDS, DTE and IA were added in the amounts of $2 \%$, $20 \mathrm{mM}$ and $150 \mathrm{mM}$ in the final reaction mixture, respectively. The concentration of the DTE is equivalent to that of SH residues contained in about $13 \mathrm{mg}$ of MT per $\mathrm{m} l$. The amount of IA added was 7.5 times that of DTE. Under these conditions, at least $1.6 \mathrm{mg} / \mathrm{ml}$ in the final reaction mixture of purified rabbi iver MT-I was completely carboxymethylated, and was detected as a single protein band when electrophoresed on an SDS-polyacrylamide gel (see below). The protein had to 
be boiled in the presence of DTE for $5 \mathrm{~min}$; otherwise another protein band, which is assumed to be an aggregated form of MT-I resulting from incomplete reduction of its $\mathrm{SH}$ residues, was also detected.

${ }^{35} \mathrm{~S}$-cysteine-labeled proteins in the cytosols of the $\mathrm{Cd}^{++}$-treated and untreated RK-13 cells were carboxymethylated as above and electrophoresed on an SDSpolyacrylamide slab gel. The fluorogram prepared from the gel is shown in Figure 1. The electrophoretic pattern of the carboxymethylated cytosol from the $\mathrm{Cd}^{++}$-treated cells showed a definite protein band that migrated with the authentic rabbit liver MTs (Figure 1, lane 1), while the pattern of non-carboxymethylated cytosol did not (Figure 1, lane 2.). This band was absent from the pattern of

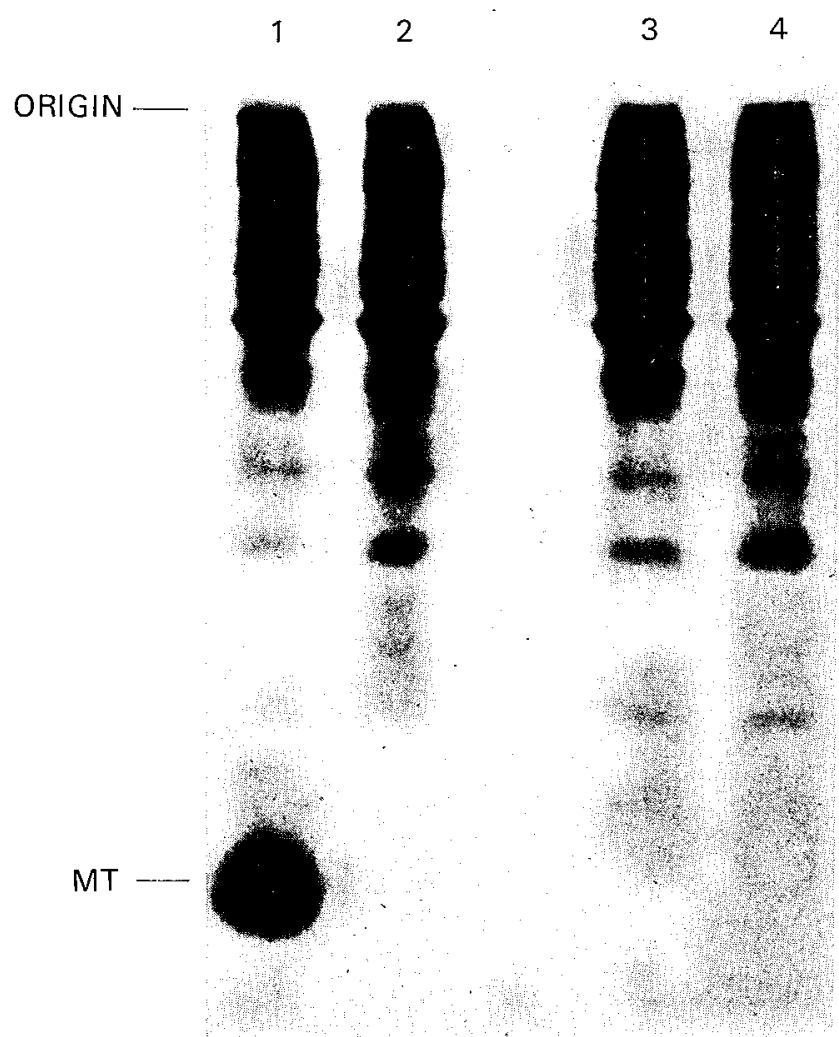

Fig. 1. Detection of thionein induced in $\mathrm{Cd}^{++}$-exposed $\mathrm{RK}-13$ cells by slab gel electrophoresis. RK-13 cells were labeled with ${ }^{35} \mathrm{~S}$-cysteine $(0.59 \mu \mathrm{Ci} / \mathrm{ml}, 34 \mathrm{Ci} / \mathrm{mmole})$ for 2 days after addition of $\mathrm{CdCl}_{2}$ (lanes 1 and 2) or distilled water (lanes 3 and 4 ) to the culture medium. The cytosol fraction, carboxymethylated (lanes 1 and 3) or not (lanes 2 and 4), was electrophoresed on an SDS-gel, and the gel was fluorographed as described in MATERIALS AND METHODS. The exposure time in the fluorography was 1 week. 
the carboxymethylated cytosol of the untreated control cells (Figure 1, lane 3), indicating its specific induction after $\mathrm{Cd}^{++}$exposure. This putative thionein band actually represents thioneins, as confirmed by amino acid analysis of the purified proteins (to be published). Thus, thioneins induced in the $\mathrm{Cd}^{++}$-exposed $\mathrm{RK}-13$ cells could be detected by electrophoresis subsequent to carboxymethylation.

It is not clear where the thioneins were located on the fluorogram of the noncarboxymethylated cytosol from the $\mathrm{Cd}^{++}$-exposed cells (Figure 1, lane 2). No apparent difference was found between the electrophoretic patterns of the noncarboxymethylated cytosols from the $\mathrm{Cd}^{++}$-treated and untreated cells (compare lanes 2 and 4 in Figure 1), suggesting that the thioneins were smeared all over the lane, possibly by forming S-S linkages with other thionein molecules or other proteins. In fact, thioneins purified from livers of mice or rabbits were often

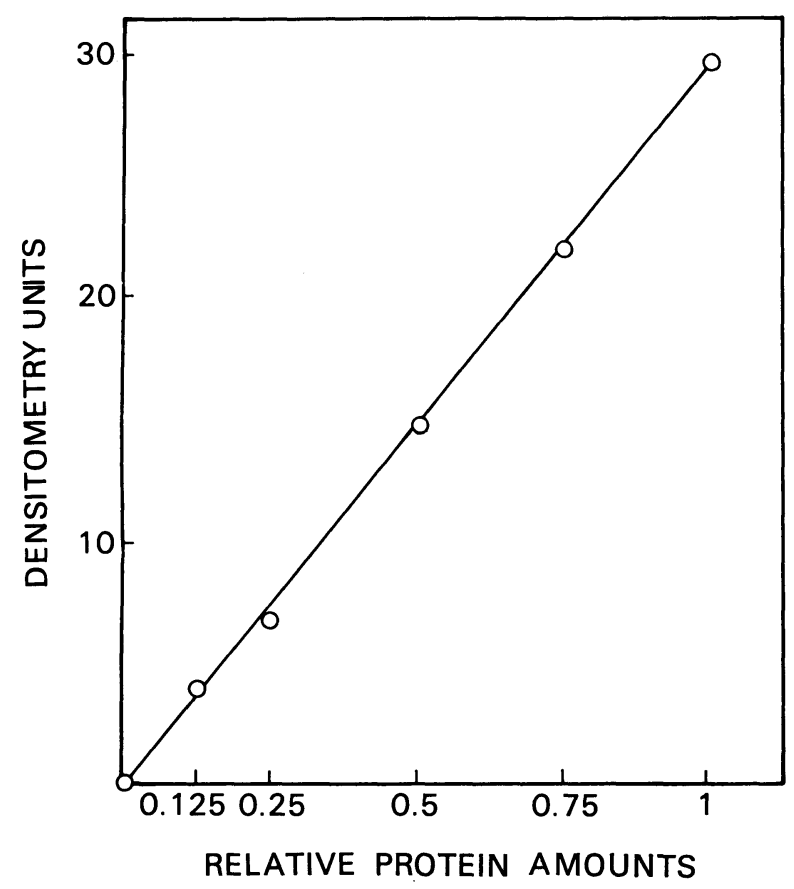

Fig. 2. Quantification of ${ }^{35}$ S-thionein by densitometry of the fluorogram. RK-13 cells were labeled with ${ }^{35} \mathrm{~S}$ cysteine $(0.33 \mu \mathrm{Ci} / \mathrm{ml}, 31 \mathrm{Ci} / \mathrm{mmole})$ for $15 \mathrm{hr}$ after addition of $\mathrm{CdCl}_{2}$. A series of dilutions of the cytosol fraction was carboxymethylated and electrophoresed, and the gel was fluorographed as described in MATERIALS AND METHODS. The exposure time in the fluorography was 2 weeks. The densities of the thionein bands were determined (ordinate) and plotted against the amounts of input protein (abscissa). 
A)

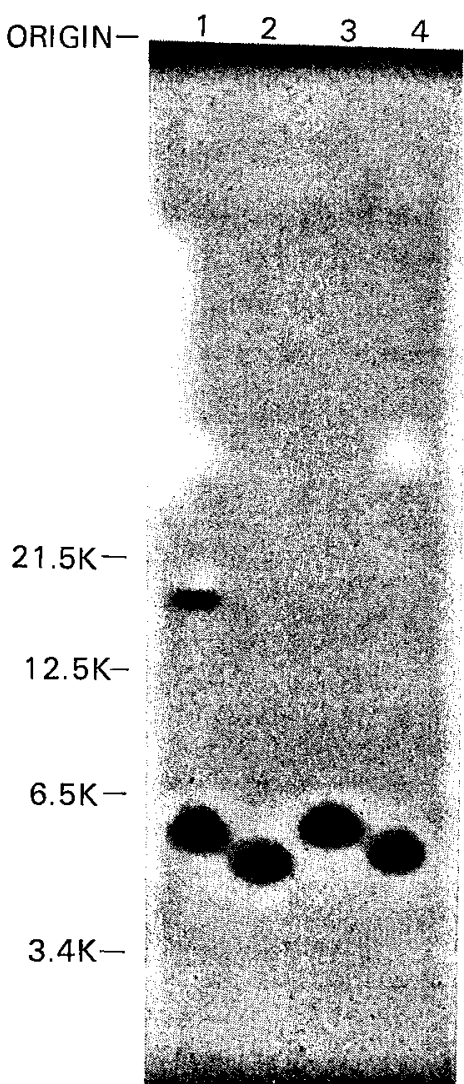

B)

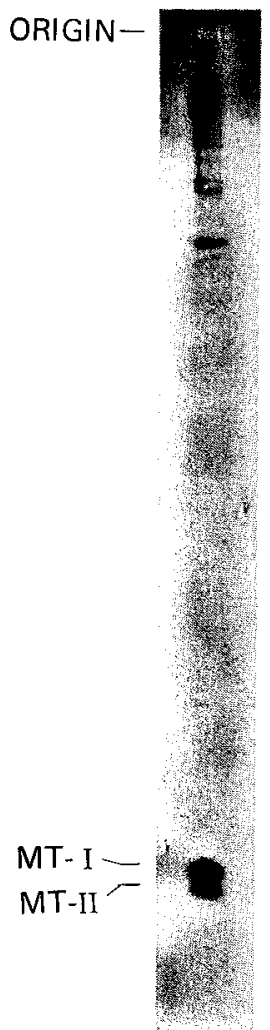

Fig. 3. Separation of isometallothioneins by SDS-gel electrophoresis. A) SDS-gel electrophoresis of isometallothioneins purified from livers of mice and rabbits. The purified preparations of mouse MT-I (lane 1) and MT-II (lane 2) and rabbit MT-I (lane 3) and MT-II (lane 4) were carboxymethylated $(375 \mu \mathrm{g} / \mathrm{ml}$ in the final reaction mixture), electrophoresed and dye-stained as described in MATERIALS AND METHODS. The mouse MT-I preparation contained a contaminating protein of 18.5 kdaltons. B) Separation of ${ }^{35} \mathrm{~S}$ tabeled isometallothioneins in the cytosol of $\mathrm{Cd}^{++}$-exposed $\mathrm{RK}-13$ cells. RK-13 cells were labeled with ${ }^{35}$ S-cysteine $(1.1 \mu \mathrm{Ci} / \mathrm{ml}, 132$ $\mathrm{Ci} / \mathrm{mmole}$ ) from 16 to $20 \mathrm{hr}$ after addition of $\mathrm{CdCl}_{2}$. Electrophoresis of the carboxymethylated cytosol was performed as descrihed in the legend for Figure 1, except that the gel was $1.5 \mathrm{~mm}$ thick and electrophoresis was continued until the BPB reached $17.5 \mathrm{~cm}$ from the starting edge of the $20-\mathrm{cm}$ running gel. The gel was fluorographed as described in MATERIALS AND METHODS. The exposure time in the fluorography was 12 days. 
distributed throughout the gels when electrophoresed without preceding carboxymethylation (data not shown).

For determining whether the relative amounts of the labeled thioneins could be obtained by densitometry of the fluorograms, a series of dilutions of ${ }^{35} \mathrm{~S}$-labeled proteins from $\mathrm{Cd}$-treated cells was carboxymethylated and electrophoresed, and the densitometrical concentrations of the thionein bands were plotted against the amounts of input protein. As shown in Figure 2 the curve was linear, demonstrating that this method is suitable for the quantitative estimation of labeled thioneins.

Moreover, we found that the two isometallothioneins (isoMTs), MT-I and MT-II, could be separated by this procedure, though they are usually detected as a single band if electrophoresed together (see refs. 7 and 8, and Figure 1). As indicated in Figure 3A, MT-I and MT-II purified from livers of mice or rabbits showed different mobilities on the SDS-gel, when detected by dye-staining. The molecular weights determined by using the standard curve of marker proteins were 5.5, 4.7, 5.8 and 5.1 kdaltons for mouse MT-I and MT-II, and rabbit MT-I and MT-II, respectively (these values are somewhat smaller than those previously reported ${ }^{5,9)}$, possibly because of high negative charge in the carboxymethyl residues, as discussed by Andersen and Weser ${ }^{7)}$ ).

Separation of ${ }^{35}$ S-labeled isoMTs on the fluorograms was more difficult than on stained gels, since the bands were more diffuse. However, it is possible to separate isoMTs by using longer gels, even when they are electrophoresed together. Figure 3B shows the fluorogram obtained from electrophoresis of ${ }^{35} \mathrm{~S}$-labeled cytosol from the $\mathrm{Cd}^{++}$-treated cells on a $20-\mathrm{cm}$ gel.

\section{Discussion}

Analysis of carboxymethylated thioneins by SDS-gel electrophoresis was first reported by Andersen and Weser ${ }^{7)}$. Enger et al. ${ }^{8)}$ reported a simpler method for carboxymethylation of MTs, and the design of our procedure was based on this method. Excess amounts of DTE and IA were added to the SH residues in the proteins, to assure complete reduction and carboxymethylaiton. By electrophoresis subsequent to this modification, we could detect ${ }^{35}$ S-cysteine-labeled thioneins synthesized in $\mathrm{RK}-13$ cells after $\mathrm{Cd}^{++}$exposure.

Since our purpose was to obtain the relative amounts of newly synthesized thioneins in many samples, densitometrical analysis of the fluorograms of the slab gels was adopted rather than measurement of the radioactivity in sections of the cylindrical gels. In this case, there remains a question of whether the density of the thionein band in the fiuorogram actually reflects the relative quantity of the labeled protein applied to the gel. Some incidents may occur; for example, the proteins may be lost from the gel during the processes after the electrophoresis or the X-ray film may not be sensitized in a linear fashion to the amounts of the radioactive proteins. At least under the conditions of the fluorography we used, 
however, the densities of the MT bands were completely linear to the amounts of the labeled proteins applied on the gel. It is thus possible to quantify the levels of thionein synthesis in up to 20 cell cultures at a time. Though the fluorograms shown in the figures were obtained after relatively long durations of exposure, the exposure time as well as the labeling periods could be shortened by using larger amounts of ${ }^{35} \mathrm{~S}$-cysteine with higher specific activity.

Furthermore, we found that the isoMTs could be separated by this procedure. On $20-\mathrm{cm}$ long gels the separation was sufficient to identify each of the isoMTs, but should be further improved for quantitative analysis by densitometry. Chemical modification of the amino acid residues specific to each isoMT may result in changes in their mobilities and better separation from each other.

\section{REFERENCES}

1) Kägi, J.H.R. and Nordberg, M. (1979). Metallothionein, Birkhäuser Verlag, Basel.

2) Hata, A., Tsunoo, H., Nakajima, H., Shintaku, K. and Kimura, M. (1980). Chem.-Biol. Interactions 32, 29.

3) Kobayashi, S. and Kimura, M. (1980). Toxicol. Lett. 5, 357.

4) Lowry, O. H., Rosebrough, N.J., Farr, A.L. and Randall, R.J. (1951). J. Biol. Chem. 193, 265.

5) Kimura, M., Otaki, N. and Imano, M. (1979). Metallothionein (Edited by Kägi, J.H.R. and Nordberg, M.), p. 163. Birkhäuser Verlag, Basel.

6) Laemmli, U.K. (1970). Nature 227, 680.

7) Andersen, R.D. and Weser, U. (1978). Biochem. J. 175, 841.

8) Enger, M. D., Rall, L.B. and Hildebrand, C.E. (1979). Nucl. Acids Res. 7, 271.

9) Tsunoo, H., Kino, K., Nakajima, H., Hata, A., Huang, I-Y. and Yoshida, A. (1978). J. Biol. Chem. 253, 4172. 